\title{
Review
}

\section{Rousseau and Hobbes: Nature, free will, and the passions}

\author{
Robin Douglass \\ Oxford, Oxford University Press 2015, x+220pp., ISBN: 978-0198724964
}

Contemporary Political Theory (2018) 17, S35-S38. https://doi.org/10.1057/s41296017-0095-1; published online 20 March 2017

This impressive study has two aims. Its "principal aim" is historical, namely "to understand Rousseau's engagement with Hobbes in its historical context" (p. 10) that is, to understand how Rousseau's reading of Hobbes as well as his exposure to eighteenth-century conceptions of "Hobbism" may have shaped his thought (p. 2). Its second aim is theoretical, namely "to show how focusing on this engagement leads to a better understanding of Rousseau's thought" (p. 10) - that is, to show how a comparative analysis of Hobbes's and Rousseau's fundamental problems and their solutions to these problems can illuminate our understanding of their projects. Combining these two modes of analysis in a single inquiry - "historical context" on the one hand, and "conceptual interplay" on the other (p. 190) - sets the bar high, but this treatment successfully combines a sophisticated reading of Rousseau's thought with an admirable methodological self-awareness.

On the first, more historical front, the author takes for his point of departure a fact that would seem on its face problematic for his project. As he notes early on, "[t]here is, in fact, no definitive evidence proving that Rousseau read Hobbes at all" (p. 17; cf. pp. 4, 20, 191). Others such as Robert Wokler have also noted this possibility that Rousseau never engaged Hobbes firsthand (p. 19), and while Douglass's notes suggest he has read widely in the correspondence and secondary literature, it yet remains the case that neither he nor others have dug up any smoking gun that can enable us to say with confidence that Rousseau engaged Hobbes's texts directly. This fact might seem to render this project a non-starter, but Douglass responds by expanding his focus to include "Rousseau's engagement both with the political thought of Hobbes and with Hobbes's ideas as they were received in eighteenth-century France and Geneva" (p. 3). The advantages of this are clear: not only does shifting from text to context gives the author broader scope for his inquiry into possible influence, but it also positions him to make an important contribution to our understanding of this context. Douglass aims to contest Jonathan Israel's claim that "no major French thinker engaged with Hobbes between Bayle and Rousseau" (p. 60; cf. p. 21), and convincingly demonstrates in

(c) 2017 Macmillan Publishers Ltd. 1470-8914 Contemporary Political Theory Vol. 17, S1, S35-S38 www.palgrave.com/journals 
response that Hobbism was in fact a prominent theme in late seventeenth- and early-eighteenth century French thought, and that Rousseau's own thought deserves to be seen as emerging at least in part from this underappreciated moment in early modern French intellectual history.

On the second, more theoretical front, Douglass chiefly aims to demonstrate "the extent to which Rousseau's political thought was concerned with problems of a fundamentally Hobbesian nature" (p. 105), even as "the manner in which he sought to resolve them was by radically inverting the Hobbesian solution" (p. 121; cf. pp. 126, 144, 189-190). This concern to show that Rousseau responded to Hobbesian problems with anti-Hobbesian solutions prompts his focus on the three specific substantive concepts on which his inquiry is largely trained, namely "the role of nature as a normative standard, the centrality and significance of free will, and the importance of cultivating the passions in the body politic" (p. 10).

Douglass's book is organized around an introduction, four chapters, and a conclusion, with the historical questions largely (but not exclusively) treated in the book's first half and the theoretical questions largely (but again hardly exclusively) in the second half. The introduction provides an extensive review of the extant scholarship on the Hobbes-Rousseau connection. It is especially valuable for how it enables Douglass to position himself vis-à-vis this literature. Here and elsewhere in the text, Douglass notes the degree to which Straussian studies have emphasized distinctively "Hobbesian readings of Rousseau" focusing on the conventionalism of his understanding of justice (p. 5; cf. pp. 106-107, 189-190). But Douglass also notes that this reading is hardly the exclusive province of Straussians; Richard Tuck likewise focuses on the "Hobbesianism of Rousseau'" (p. 6; cf. p. 138). For his part, Douglass aims to offer an alternative to both readings, one reminiscent of the sort of alternative that scholars such as David Williams have also sought to extend - a similarity the author himself notes in detailing his differences with Williams (see e.g., pp. 5, 137-138).

Chapters One and Two then turn to the question of historical influence. The first chapter examines how Hobbes was engaged by late seventeenth- and earlyeighteenth century French thinkers. Douglass's brisk but careful tour through the key episodes in this engagement begins with Bayle's influential article on Hobbes in his Dictionnaire and Pierre Nicole's neo-Augustinian treatment of the relationship of self-love to charity, before turning to Malebranche's critique of the consequences of Hobbesian empiricism, Burlamaqui's and Barbeyrac's understanding of Hobbes in the context of early modern natural law, and the critical treatments of Hobbes to be found in Montesquieu and the Encyclopédie. Chapter Two shifts from context to text, offering a reading of Rousseau's invocations of Hobbes in the second Discourse. It argues for three specific claims. First, Rousseau is a critic of both Pufendorf and Hobbes; however, much they all might agree on the primacy of the desire for self-preservation, failure to appreciate the role of natural pitié compromised Hobbes just as reliance on natural sociability 
compromised Pufendorf (pp. 63, 68-69, 88 ff.). Second, Rousseau's emphasis on the primacy of free will emerged in the context of engaging Hobbes and served as a tool for Rousseau to critique both Hobbes and his natural law critics. Third, Rousseau conceived of nature as a "normative standard" to which "any form of the good life must conform," and which he "set forth in opposition to Hobbes's account of the state of nature" (p. 64; cf. pp. 95, 140 and passim.).

Chapters Three and Four turn from textual and contextual influence to argue that Rousseau's political thought deserves to be seen as an attempt at "overcoming problems of a fundamentally Hobbesian nature" (p. 9). The key problem for Rousseau is said to be "placing law above man" (p. 104) - a problem for Rousseau precisely since he "accepted the problematic of Hobbes's state of nature to a far greater extent than any of his contemporaries" (p. 112; cf. pp. 114, 148). Yet Rousseau of course rejected the solution given by Hobbes. The problem with that solution, says Douglass, is that it compelled the sacrifice of both free will and nature; in his words, "Rousseau insisted that any legitimate social order would have to be established without man becoming dependent on someone else's will," and also by preserving "nature as a normative standard" (p. 104; cf. p. 124). Chapter Four furthers this inquiry into Rousseau's anti-Hobbesian solutions to Hobbesian problems by examining their differing accounts of the optimal means "of ordering the passions to secure political unity" (p. 150). Noting that "[f]or Hobbes, above all else, it was man's fear that needed to be rightly ordered," whereas "for Rousseau it was man's love" (p. 10), Douglass builds on a scholarly consensus that emphasizes how Rousseau channeled potentially destructive selflove to socially beneficial ends by putting it in the service of love of fatherland (e.g., p. 163).

On the whole, all of these claims are persuasive and illuminating. On two other fronts, however, I would press the author. First, Douglass is keen to "dispel[] the proto-Kantian readings of Rousseau that abound" (p. 151; cf. pp. 14, 170, 185). Douglass's main claim on this front is that however much autonomy language the two thinkers may seem to share, at the end of the day Kant thinks reason should master the passions, where Rousseau thinks "the role of reason was not to master or overcome the passions, but simply to order them" (pp. 14-15; cf. pp. 177, 195). Yet the arguments adduced here (see pp. 171-177) may not convince all readers that Rousseau cannot usefully be read as anticipating Kant when he calls for Émile "to sacrifice inclination to duty and to hold out against your heart in order to listen to your reason" (Rousseau, 1979, p. 444). Second, Douglass offers an innovative reading of Rousseau's notorious comments regarding the political necessity of "denaturing." On this front, Douglass claims that Rousseau "paradoxically" envisioned denatured man as yet "in accordance with the order of nature" (pp. 142-142; cf. pp. 11, 165). This is an intriguing way of reconciling the commitment to nature as a normative standard with Rousseau's emphasis on denaturing, but it's hard not to wonder whether such a solution might not understate the tensions that

(c) 2017 Macmillan Publishers Ltd. 1470-8914 Contemporary Political Theory Vol. 17, S1, S35-S38 S37 
seem to exist between Rousseau's varying ideals, as personified by the natural savage, the citizen, the solitary walker, and Émile.

These, however, are relatively minor quibbles with what is on the whole an impressive and rewarding study. It is rare to find a book that so self-consciously and effectively employs the tools of both the historian of political thought and the political theorist. Moreover, I admire the author's efforts not only to work through the voluminous scholarship on both figures, but also his efforts to acknowledge his debts to previous scholars who anticipate his claims, and his efforts to isolate with clarity and precision the several instances where he breaks new ground. For all of these reasons, Douglass's book will be important for readers of both Rousseau and Hobbes to engage.

\section{Reference}

Rousseau, J.-J. (1979) [1762]. Émile, or On Education, trans. Allan Bloom. New York: Basic Books.

Ryan Patrick Hanley Marquette University, Milwaukee, WI 53233, USA ryan.hanley@marquette.edu 